\title{
Planning and Design Attributes of Preplanned Postmodern Capital Cities: A Comparative Study
}

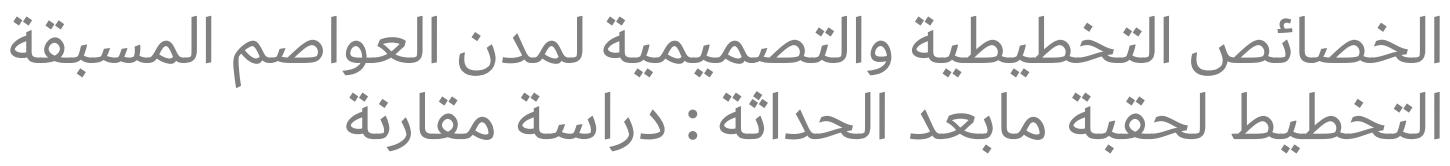

Abdelwahab A. Alwehab ${ }^{1}$ and Martina Juvara

الدكتور عبدالوهاب احمد الوهاب ومارتينا جوفارا

${ }^{1}$ Urban and Regional Planning Center for Post Graduate Studies, University of Baghdad, Baghdad, Iraq

²Director, URBAN SILENCE Ltd., London, United Kingdom

Corresponding Author: Abdelwahab A. Alwehab alwehab@gmail.com

Received: 28 December 2017 Accepted: 2 February 2018

Published: 1 May 2018

Publishing services provided by Knowledge $\mathrm{E}$

(c) Abdelwahab A. Alwehab and Martina Juvara. This article is distributed under the terms of the Creative Commons

Attribution License, which permits unrestricted use and redistribution provided that the original author and source are credited.

Selection and Peer-review under the responsibility of the Urban Planning Iraq Conference Committee.

\section{Abstract}

Capital cities command a prominent position within the urban hierarchy, where in many countries they are the most significant city, as well as the economic, and cultural hub of nations. Capitals are under continuous infrastructure, economic, social, and environmental pressures to accommodate rapid urban growth. Therefore, some countries elected to relocate their Capital city. For purposes of comparison, a sample composed of five nations who relocated their Capital within the postmodern era were selected. They are from diverse geographic in Asia, Africa, and South America, as well as from varying economic and cultural background. New Capitals are analyzed in an attempt to explore the urban planning models implemented by these cities. The research work aimed to unravel the mechanisms utilized by Planners and Political leaders to bring their vision of the desired Capitol City to reality. It was evident that every case had its idiosyncrasies, and not all Capital projects realized the desired outcome. Planning and design principles were developing in the right direction to conform to contemporary urban planning and design practice. Future studies must address the impact of the digital revolution on the functional aspects of capitals layout.

تحتل مدن العواصم موقع بارز ضمن التسلسل الهرمي للمناطق الحضرية ، حيث في العديد من البلدان هم

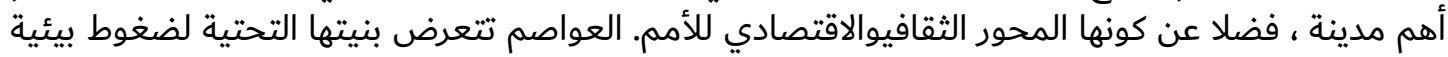

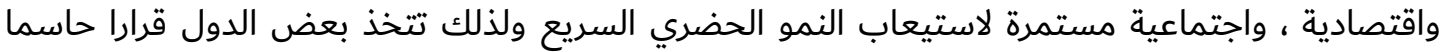

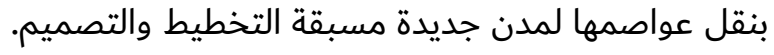


لأغراض المقارنة تم انتقاء عينة تتألف من خمس دول نقلت عواصمها في عصر ما بعد الحداثة .تتألف ألفأ

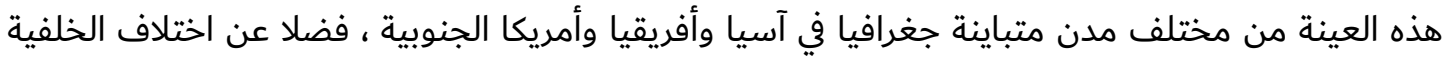

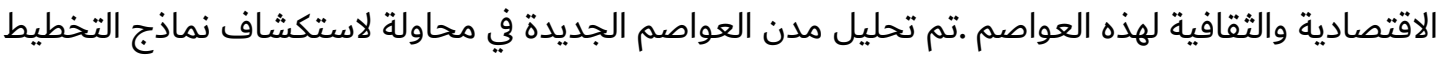

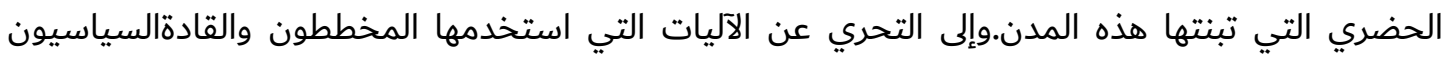

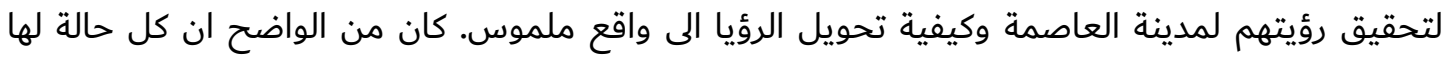

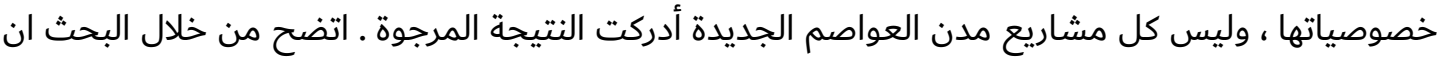

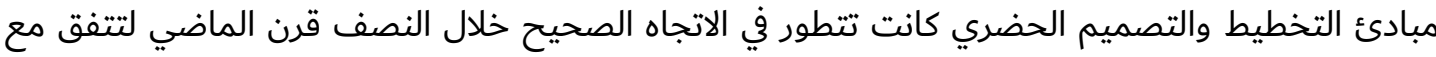

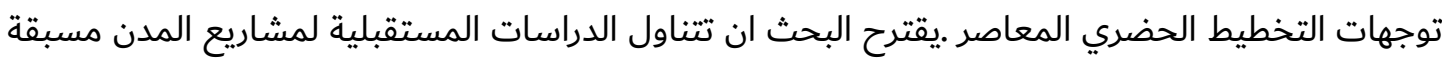
التخطيط تأثيرات الثورة الرقمية على الجوانب الوظيفية لتخطيط وتصميم العواصم الجديدة .

Keywords: Capital Cities, Preplanned capitals, Modern Era Cities, Capital Urban planning, Garden Cities

مدن العواصم, العواصم مسبقة التخطيط, مدن العصر الحديث, التخطيط الحضري للعواصم, المدن الحدائقية

\section{INTRODUCTION}

Capital cities most commonly defined as the seat of a country's government and administrative center. They are commonly the showcase of nations and a source of pride to citizens. The prominence of their position in the urban discourse is due in principle to the size of capital cities, which in many countries around the world constitute the largest urban center in the nation. History of planning and redesigning capitals commenced before the emergence of town planning as an established discipline. When Haussmann was embarking on the redesign of Paris as the French nation capital, urban planning was not an established professional discipline guided by agreed-upon values and principles. Instead, terms such as Improvements, Extensions, and Embellishments were in circulation at the time to define the practice. The latter decades of the nineteenth century witnessed the emergence of new terminology, which introduced "Town Planning" as an established profession. This new norm gave rise to the modern phase of urban planning and provided momentum to the rethinking of capitals' design and planning [1]. As Planning and Architecture developed in the second half of the twentieth century, so did the principles and methods applied in urban planning in general, and in capital cities in particular. This research work attempt to inquire into the debates and principles which guided the development of preplanned capital cities during the modern and postmodern era of architecture and urban design. Selection of case studies for this Article is dictated by the fact that these capitals 
are the most prominent examples of greenfield preplanned development within the postmodern era.

\section{REASONING AND MOTIVATION}

It was in national capitals that the adverse outcomes of excessive colossal city development were more severely evident than other towns since urban capital centers were, in general, more prominent than the following greatest city in any given nation. It was there that the acute conditions were seen and talked about at the national level. It was there that legislatures had a specific enthusiasm for interceding and endeavoring to enhance conditions, and it was there, as the world has seen, that numerous extraordinary ventures were embraced to create better capitals cities [1]. Such new capitals differ substantially in their urban planning principles. They vary in function but share common objectives mainly Administration, symbolization, integration, and preservation of cultural monuments [2]. Furthermore, many capitals attempt to incorporate a multitude of parameters to shape the physical space. State's security, fairness, identity, economic and administrative effectiveness are among such parameters [2]. Peter Hall identified seven types of capital cities. His categorization includes Multifunction, Global, Political, Ex-Imperial, Provincial, Super, and Former Capitals. [3]

Over a period of forty years, the world has witnessed the emergence of a Preplanned capital cities trend. "From 1950 to 1990, thirteen countries including ones in Latin America, Africa, and the former USSR moved their capitals. This occurrence across space and time impels the investigation of logic and motivation of decision makers in these countries to undertake such an expensive and risky strategy. Among the many plausible answers to such inquiry can be that capital relocation is one of the more innovative tools for building states and national identity" [3]. The impetus for the relocation decision can be narrowed into two broad categories. The first is political, and the other is related to the inefficiency and congestion of exiting capital cities. Some of the decisions were based on necessity as new states are being created. It is an immense undertaking, and most leaders and public officials are apprehensive of taking charge of the political, financial, and logistical costs. On the other hand, many new capital projects were over-ambitious regarding attainable organizational, as well as financial resources, and have resulted in blunders [3].

Older developed countries were more reluctant in relocating their capitals despite their expansion regarding population, area, or inflated land cost. This phenomenon was demonstrated in the hesitation of the Japanese government since 1960 to move the capital seat from Tokyo to another location. The city of Sendai in the north and Nagoya 
were considered as a favored alternative. However, the proposal did not see the light of day. In the 1990s the idea of relocation was revisited as a result of the explosion of urban land prices, but calls to relocate never materialized. A similar debate took place from time to time in Great Britain to move the capital London, but such proposals were not taken seriously enough. The only exception in this regard was the relocation of the Federal German capital to Bonn, but this event came as a result of the division of the country following WWII.

Capital cities are not an ordinary urban center. Their function goes far more significant than an agglomeration of the population an elaborate infrastructure. As Amos Rapoport, the Polish Architect puts it "Capitals provide stages and props for ceremonies and rituals-that has been called shrines or theatres of power...By using appropriate repertoires, political authority is communicated, and relevant institutions appear mighty, impressing large audiences. Appropriate elements dramatically communicate culture-specific schemata of political authority, act as mnemonics, legitimate acts, secure compliance and reinforce the official definition of the state" [4].

\section{PREPLANNED CAPITALS: FROM CONCEPT TO REALITY}

The Modern Age of preplanned capitals may have commenced with the resolution to build Brasilia to be the new capital of Brazil. Circumventing economic, social, and infrastructure constraints and complications become more feasible with the selection of a greenfield site to erect a new city.

TABLE 1: POSTMODERN PREPLANNED CAPITALS [4].

\begin{tabular}{l|l|l|l}
\hline Case & Year & New Capital & Former Capital \\
\hline Brazil & 1956 & Brasilia & Rio de Janeiro \\
Mauritania & 1957 & Nouakchott & Saint Louis (Senegal) \\
Pakistan & 1959 & Islamabad & Karachi \\
Botswana & 1961 & Gaberone & Mafeking \\
Libya & 1963 & Tripoli & Benghazi \\
Malawi & 1965 & Liliongwe & Zomba \\
Belize & 1970 & Belmopan & Belize City \\
Tanzania & 1973 & Dodoma & Dar es Salaam \\
Nigeria & 1975 & Abuja & Lagos \\
Ivory Coast & 1983 & Yamoussoukro & Abidjan \\
Germany & 1990 & Berlin & Bonn \\
Kazakhstan & 1997 & Astana & Almaty \\
Malaysia & 2000 & Putrajaya & Kuala Lumpur \\
\hline
\end{tabular}

Table 1 provides a chronological list of preplanned capitals throughout the globe where nations decided to erect new capitals or relocate their capitals to an existing nucleus towns. Some preplanned capital cities are presented here to lay out the evolution of urban planning pattern through the modern and postmodern age of planning 
and design. The case studies come from diverse geographical locations, cultural backgrounds and span three continents in the southern hemisphere, namely Brasilia from the modern era, in addition to Putrajaya, and Astana, in Asia, as well as Dodoma, and Abuja in Africa.

\subsection{The Automobile Age Capital: Brasilia}

Brasilia is perhaps the largest city in the world that did not exist at the beginning of the 2oth century. Brazil had contemplated the idea of moving its capital from the coastal area to the remote hinterland for more than two centuries. This dream became a reality in 1956 with a declaration of the then Brazilian President Juscelino Kubitschek to build a new capital city in the deep interior and to be launched by the end of his term as president. An international Jury committee was given in the following year the task of selecting a unique urban design scheme for the new city. The winner of the national design and planning competition was Lucio Costa who developed a master plan for the new capital referred to as the Pilot Plan "(Plano Piloto)" of Brasilia as shown in Fig. 1 $[5]$.

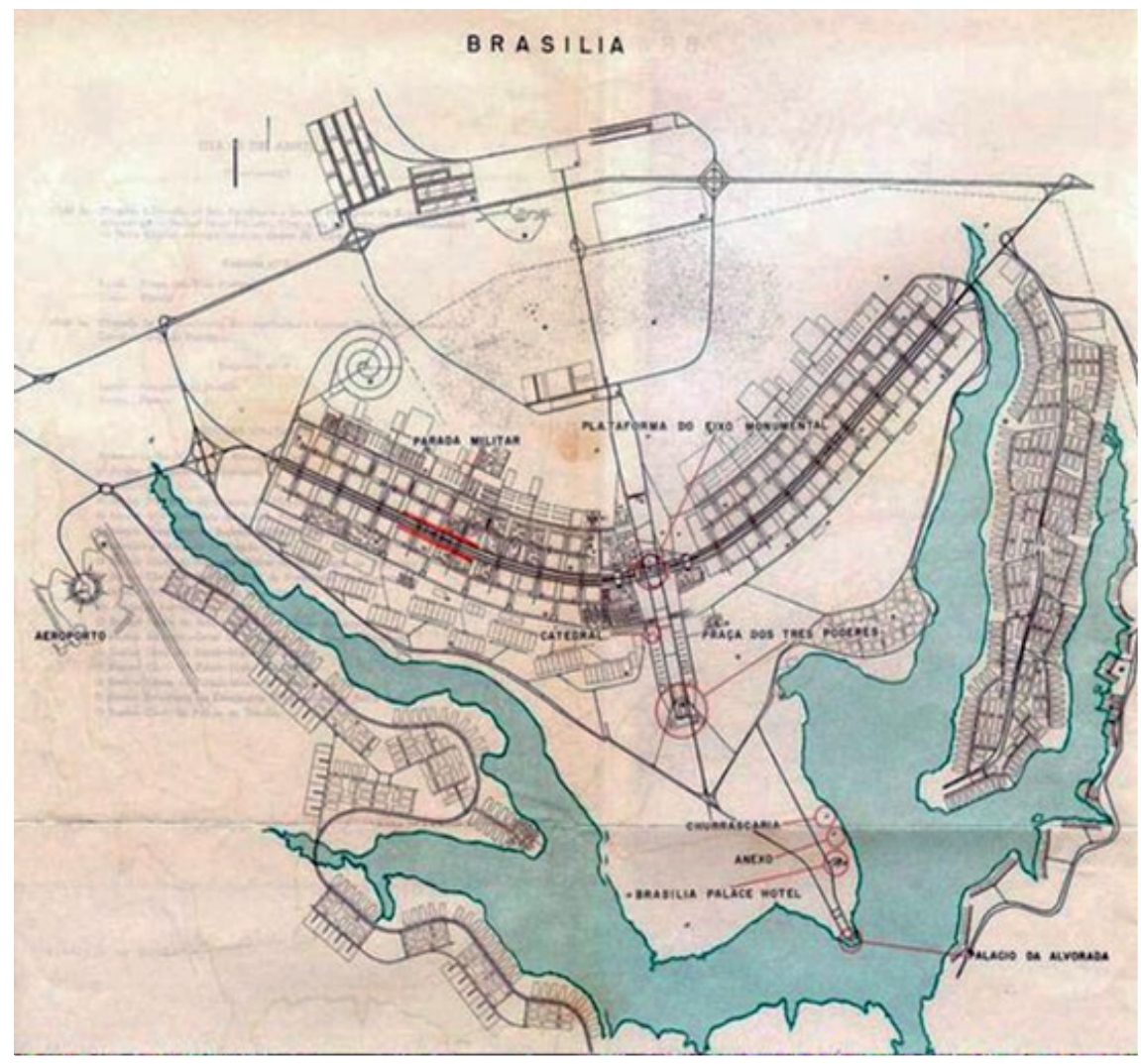

Figure 1: Plano Piloto - Brasilia [6]. 
Optimal city size was a notion most city planners believed in at the time when Brasilia was being designed by Costa. He was a follower of this concept and saw that a city beyond this limit becomes out of control. Planning of cities within this optimal size was thought to be the responsibility of urban planners and public officials. Brasilia was designed to an optimal size of 500,000 residents. Population growth far exceeded what was anticipated, and in reality, the number of inhabitants hit the optimal mark by 1970. A significant drawback to adopting the fancy of optimal size resulted in an urban scheme with no room for expansion. Costa's adherence to this principle whether intentional or not, left the city surrounded with man-made barriers. To the northwest, the great national park, and a lake enclosing the city center to the south-east constituted permanent obstacles to any future expansion of the city [6].

The design criteria for the capital city of Brasilia was a textbook case of Modern era urban design principles. The urban pattern linkages were dominated by the automobile as the sole mode of movement. No proper consideration was allotted to other modes of transportation such as pedestrian and bicycle, contrary to all Post Modern urban planning principles. The outcome of this plan was distinctively low densities in the core, with expansive high-density suburbs occupied by low to mid-income population, which resulted in the sense of physical isolation and fragmentation among various districts of the city.

The idea of embracing Costa's original plan was a significant concern for Government's planners. They aimed to retain the high physical standard put forward by the plan as far as housing and infrastructure, where they saw in the plan a classic case of "Exceptional Urban Planning." The plan could have been more successful if it had averted imperfections stemming from the lack of adequate supply of housing land to meet the needs of the incoming workforce to the new capital. The "Plan Piloto" as envisioned by Costa was not out of sync for its historical period, and it followed a historical trend within the planning context at the time [6]. Brasilia, nearly fifty years after its inauguration, is home to 2.5 million inhabitants. Regarding area size, it ranks as the fourth largest urban center in Brazil. The central urban pattern of the original pilot plan has remained as envisioned by the Costa, where most of the upper middle class live in central areas of the city. The most striking element of the city is that only 10 percent of the total population resides in the municipal boundaries, and the rest of the population commute to 27 satellite towns within the federal zone [5]. Housing districts in the city were designed for a population of 500,000 thousand subdivided into neighborhood units and organized within superblocks providing all necessary social, medical, and commercial infrastructure. These superblocks were aligned along an arched expressway running from the north to the southern districts. 
There was a prominent separation between public and private space within the urban pattern, to separate housing areas from official and civic buildings [5]

\subsection{Commencement of Smart Planning: Dodoma}

The Independence of Tanzania in 1961 brought about an enthusiastic sense of nationalism and was eager to establish pillars of a unique identity and symbolism to join the rank of rising nations. In 1973, the government of Tanzania made a bold declaration to erect a new capital city in tandem with other emerging third world nations. The rationale behind this decision was to narrow the distance between the government and citizens with a more central positioning of the seat of government.

The peripheral location of the old capital city Dar es Salaam has contributed to the relocation decision. Such position rendered governmental departments inaccessible to the majority of the population [12]. Design and planning principles of the new capital city were based on the classic concept of "Garden City" which was incorporated in the 1976 masterplan and extending to the "Cities" concept of 1988.

There were several reasons for selecting Dodoma as the new national capital. The issue of development has been the main reason for shifting the capital, but there were other benefits which the country gains due to the shift. Among those are the need for capital to be a source of national pride, eliminating expensive city management cost of existing capital, and the noticeable weather pleasantness in Dodoma region, where the relative humidity is about $20 \%$ less than Dar es Salaam. In 1975, Dodoma was a small town of 53,000 inhabitants with a somehow central position and a major regional center [7]. It is at the crossroads of the Great North Road between Arusha and Mbeya and the east-west road from Dar es Salaam to Mwanza/Rwanda, and it had an existing infrastructure which can reduce initial costs of building the capital. The master plan of the new capital city highlighted Tanzanian cultural, political symbolism and identity although the plan was based on international models of urban planning and design. An ad hoc "Ministry of Capital Development" was created in addition to an operational entity namely the "Capital Development Authority" (CDA). Both entities were the governmental arm responsible for the development of the project and bringing it to reality. In 1974, the Canadian firm Macklin Hancock of Project Planning Associates Ltd (PPAL) was granted the task of drafting the master plan, as well as physical planning and design of the new capital Dodoma [8].

The master plan of the mid-1970s stipulated that the core of the new capital should contain the small existing town as well as the National Capital Center and related activities. Housing districts were designed as integrated communities and aligned along the 
central core of the city. The general urban plan of the city emphasized a linear layout with communities organized in layers, with dispersed employment centers arranged around bus routes and bike paths (Fig. 2.).

The excellent urban planning vision of the new capital was in sync with contemporary new urbanism. The design elements applied were cutting edge and environmentally sensitive. "The main concepts of the 1976 plan included a hierarchy of service centers with shopping, places of worship and recreation, Public transport based on buses, cycleways and pedestrian paths, mixed-income residential communities, conforming to Tanzania's policy of socialism and self-reliance, Low rise buildings, a garden city each community of 25,000 was to be circled by a green belt to serve as boundaries between communities also to be used for small-scale farming by residents of the area. The capital city was to be surrounded by an afforestation belt of 22,000 hectares, and the Urban renewal of the old town" [8].

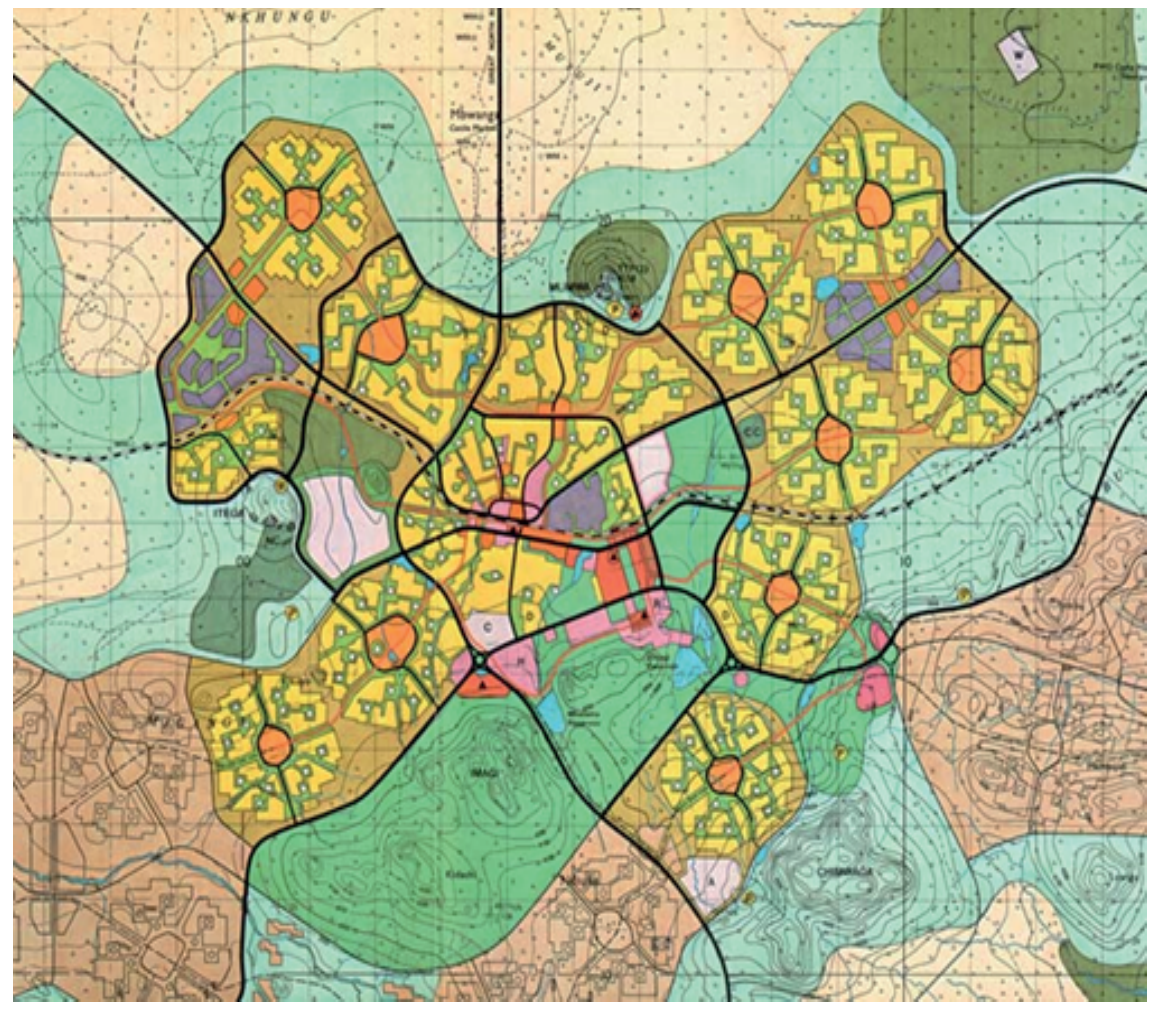

Figure 2: Dodoma masterplan [9].

The urban design scheme and guidelines of 1976 for the Tanzanian capital attempted to accentuate the urban shape and form to leave residents and visitors with a memorable experience. Visual elements, infrastructure facilities, landscaping, orientation, and urban form were integrated into the guidelines to provide inhabitants with an exulting urban experience. The urban design plan affirmed the correlative and integral relationship between residents, landscape, and the land itself. The plan furthermore 
advocated mixed land use (residential, commercial, and cultural) within the CBD of the National Capital Center (NCC). In 1979, the New York urban design firm Conklin and Rossant was selected to assume responsibility as urban designers for the city.

The plan despite the forward-thinking and novel approach did not achieve its full potential. There is a multitude of reasons behind this outcome. Perhaps the main issue was not enough resources allotted to carry out the vision stipulated in the plan. Resources missing were not merely material, but somewhat political where the will of leaders did not back this ambitious plan. As a consequence, the desire to move to the new capital from civil servants and politicians were not enthusiastic. This reality of the 1976 master plan prompted an analysis and revision of the existing plan bearing in mind the economic outlook of the country. Cameron McNamara of Brisbane, Australia was selected in 1988 to review the original plan and make adjustments in light of strengths and weaknesses of the old plan. The outcome of the revision culminated in adopting a new vision of the urban development of the capital more suited to the economic and cultural realities while taking into consideration the natural environment surrounding Dodoma. The new approach abandoned the concept of organic growth around the existing small city as indicated in the 1976 plan, and leaned toward the creation of new towns with a population size ranges from 90,000 to 120,000 to support the growth of the new capital.

The declared advantages of the new plan were to reduce costs, creating a choice of settlements areas, and avoid monotonous linear expansion of communities. It is interesting to find that public officials were keen to incorporate measures into the master plan which portray smart growth during the seventies of the last century, much earlier than the emergence of the concept in contemporary Planning discourse. The residents of the New Capital of Dodoma will be encouraged to walk to work. The immediate implication translates into residential houses and flats are built closer to the working places to reduce transport trip durations, and polluting agents in the town will be reduced as much as possible [7]. The implementation of the 1988 new master Plan has progressed slowly as well due to a shortage of funds, and minimal political will from the government, accompanied by lack of enthusiasm from commercial and industrial sectors [8].

\subsection{Symbol of Unity: Abuja}

The Nigerian government decided in the early 1980 s to build a new a capital city as a gesture of unification of the nation as it emerges as a fledgling economic powerhouse in Africa. The decision came as result of the deliberation of a select committee namely 
the "Akinola Aguda Panel" to decide the future of the existing federal capital city Lagos. The panel determined that Lagos can no longer sustain uncontrolled rapid growth due to unmanageable land use problems. Thirty towns were proposed as candidates to relocate the new capital based on some suitability criteria as nucleus towns for the new capital city. None of these towns were deemed appropriate, and the panel elected Abuja, a greenfield site to be the future capital of Nigeria (NCC). The first physical development master plan for Abuja was drafted in the early 1980 s with a preliminary inauguration timeframe around the year 2000 [10].

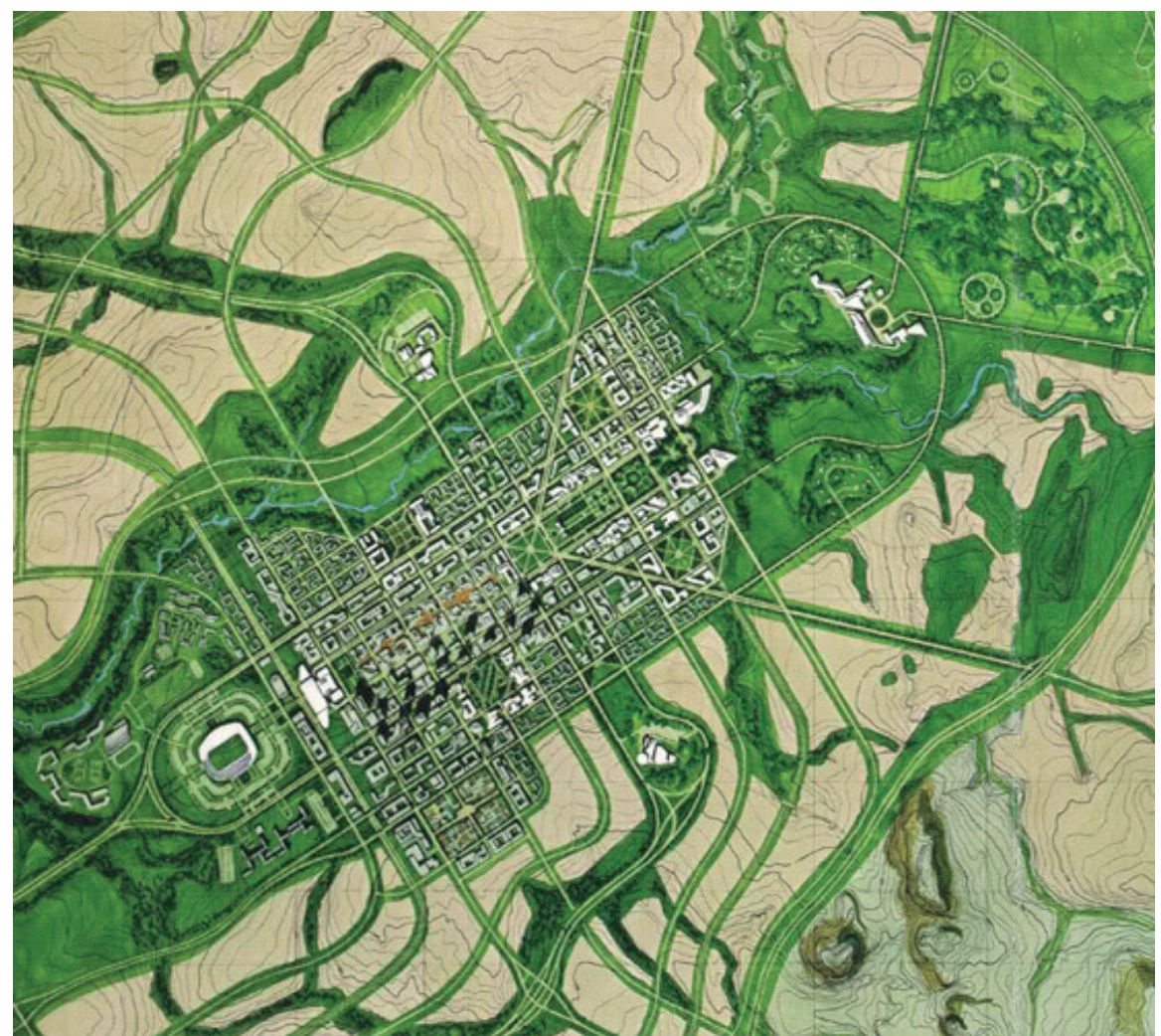

Figure 3: Abuja's layout [11].

The implementation of the new project was assumed by the Federal Capital Development Authority of Nigeria, where in June 1997 it contracted "International Planning Associates" (IPA) to draft the Capital's first master plan along with its regional hinterland [11]. The history of Nigeria was reflected in the design and planning framework of the new city. It was meant to serve as a symbol of Nigeria's ambition and strength and to break away from its recent past as a British colony in the early $20^{\text {th }}$ century composed of a large number of ethnic and religious backgrounds [10].

The new capital was envisioned to be a seat of government, with a healthy social, economic, and natural beauty where all the diverse cultures of the nation can visit, reside and enjoy its modern landscape. The city is conceived to represent a beacon of 
unity, a source of pride, and a showcase to the world [10]. The principal urban design concept revolved around the Functional City paradigm highlighted by a crescent built structure with a commanding position in the northeast sector of the new city with an axial vista to a high point of Aso Hill. The Masterplan was comprehensive and broad in its content. It was intended to harmonize all vital functions, and land uses, including Housing, Transportation Network, Commercial, Recreational, Infrastructure, Industry, as well Agricultural areas. The plan acknowledged the interrelationships and interdependence of these functions and aimed to coordinate the spatial dimension for maximum efficiency. "The Master Plan has four (4) phases with incremental planning model of staged growth planned to occur in stages so that construction of one sector is completed before the next is begun to reduce the impact of noise, dust, and disruption accompanying a continuous long-term construction program as foundation for implementation" [12].

The city as a "Public Place" for the citizens of Nigeria was a major catalyst of the overall urban design scheme of Abuja. This objective was featured strongly in the master plan primarily in the central zone. Nature and design characteristics were carefully laid out and encompassed the location and balanced configuration of space. Sites were not readily available and had to be trade-offs with areas of other functions. However, in reality, the implementation of these spaces was lagging behind and hampered planner's efforts to celebrate the original scheme of Abuja as the city for all via Public Space principle [10]. Out of the multitude of sites marked for conversion into attractive and inviting public spaces in the central area, only one site was developed, and the rest were sadly left either unfinished or dispensed with altogether. One such site regrettably eliminated is the central Mall based on Pierre L'Enfant's concept of the central open space Mall in the American capital Washington DC. As Mabogunje, a leading Nigerian Geographer stated concerning the abandonment of the Mall concept: "The idea behind the Mall, of course, was to make the City a lot more pedestrian-friendly such that people can move around and enjoy their Capital City between discharging their business with various government ministries [10].

\subsection{Leadership Self indulgence: Astana}

Kazakhstan, a central Asian country and part of the former Soviet Union, resolved to move its capital in December 1997, in a historical period categorized as Contemporary. The capital city relocation was from Almaty in the southeastern part of the country to Akmola in the north-central region of Steppe. The city was later renamed to Astana. The decision was not made in an appropriate timeframe in the history of 
Kazakhstan, where it was going through a downward economic trend. Industrial and agricultural output was decreasing, health and education system was crumbling, along with high rates of unemployment [4]. Nonetheless, the move was justified for geological, environmental, and physical complications. Scientists forecasted that Almaty would go through destructive earthquakes in the near future due to its location in a zone of intense seismic activity. On the other hand, its location along the Zailiiskii Alatau mountains made future southern and eastern urban expansion prohibitive and limit further economic development in these directions (Fig. 4.). This very same locational characteristic compounded the ambient air quality by trapping air contaminants and resulting in an unacceptable air pollution levels [4]. However, political and ethnic motives were not far behind, if not superseding others.

The leaders of the country wanted a new capital city that would position Kazakhstan as an influential actor within the international community. The international aspirations of Astana to be an enticing urban center on the world stage was a prime force in the urban design and architecture of the city. Modern buildings were erected to serve as governmental departments depicting the self-indulgence of its leadership. Cultural structures are spreading across the urban landscape ranging from museums, beautiful parks, public plazas and spaces reminiscent of the European neo-classic style of European capitals.

Citizens did not universally embrace the urban plan of Astana. There was an impression by segments of the population viewed the new capital as a modern-day "Potemkin Village" erected to lure international investors. History will judge the validity of this impression, but current indications verify that Astana is a flourishing capital.

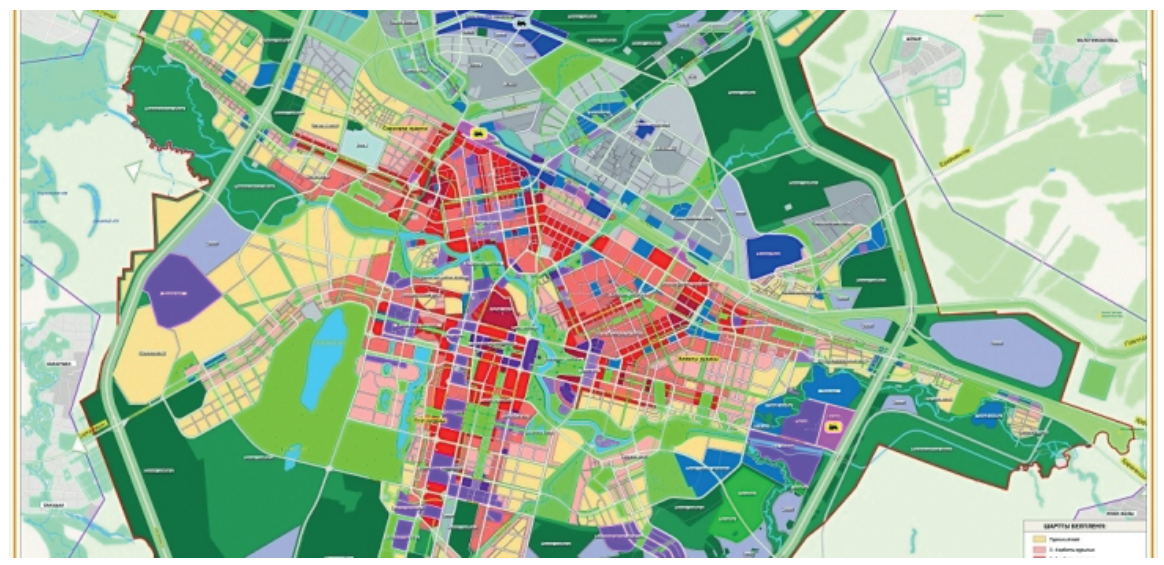

Figure 4: Astana Master Plan [13].

Nation building strategies in Kazakhstan emphasized the creation of unifying symbols to appeal to the multicultural and ethnic landscape of the nation. The political leadership contrived the concept of "Eurasianism" and advanced it as a set of symbols 
to unify the nation and appeal to the Non-Kazakh population. Kazakhstani leaders established enigmatic cultural aggregation designed to foster universal appeal and broad resonance with citizens. In this sense, relocation of the capital was a symbolic resource offering alternative visions of nationhood [4].

\subsection{The Federal Capital: Putrajaya}

The debate of relocating the seat of government in Malaysia has lingered since 1993. Six sites were selected to be the next Federal capital and Government Administrative Center of the country. It can be said that the idea was not politically motivated. The debate unfolded as a result of a genuine concern for maintaining a high standard of living and environmental conditions for the inhabitants of the capital city. The relocation was regarded as the mechanism of a pressure valve to relieve the mounting demand on urban land in the already overloaded capital city of Kuala Lumper. The demand for government office space and modern infrastructure facilities in Kuala Lumper was growing at an unprecedented rate and has stretched available capacities in the city to their limits. Extracting governmental and civil service functions away from KL to a well designed urban center equipped with the highest standard of facilities and modern technology ensures higher performance and efficiency for the country as a whole [14].

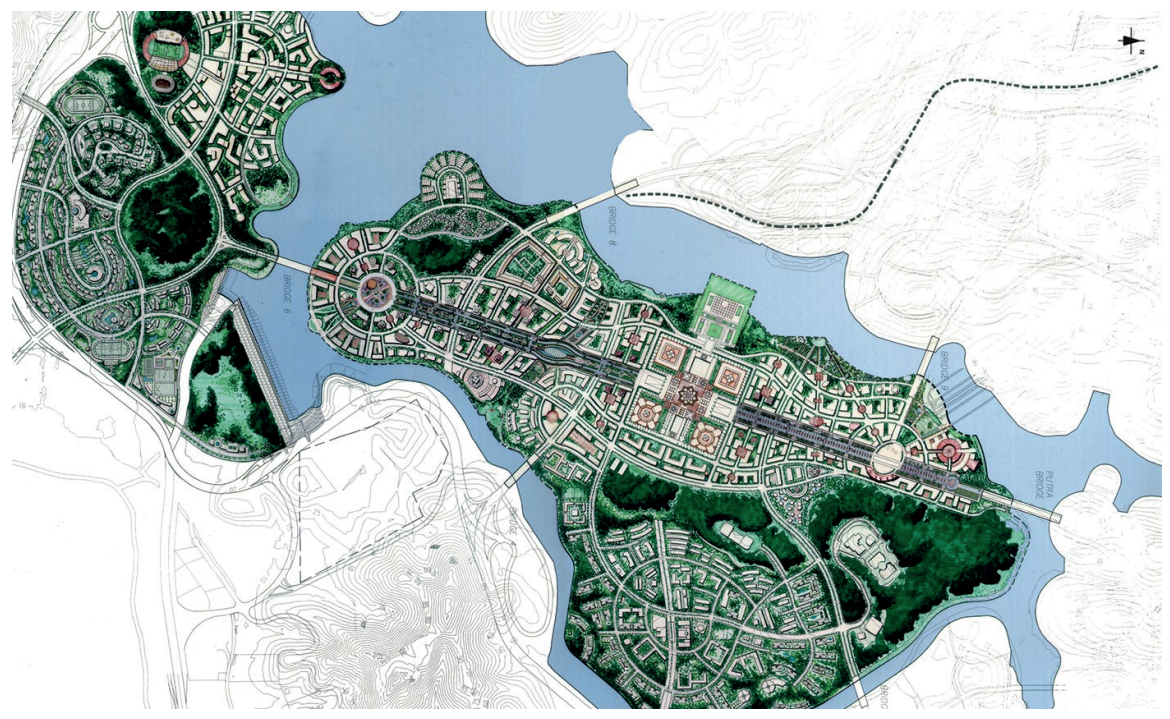

Figure 5: Masterplan of Putrajaya [15]

The interpretation of cultural values into an Urban Master Plan in a country of the multi-religious, ethnic, and racial background was a significant opportunity as well as a challenge for the Malaysian urban planners and designers. The planning, development, and construction of the new capital project were carried out mainly by the local workforce. The Putrajaya capital project is considered the most extensive greenfield 
urban development and destined to be a model of sustainable urban planning [16]. The Site selection process followed specific locational prerequisites emphasizing economic, accessibility and environmental parameters. Location Criteria elements of reference are : Land acquisition and infrastructure cost, Strategic location within a growth corridor, Good accessibility to major transportation network (rail, highways and ports,) Presence of pristine natural vegetation and landform, Potential for positive externalities to the neighboring regions, and Minimal adverse impact to local communities [14].

Total land area of Putrajaya, the new capital city, is 14,780 hectares (Fig. 5.). $30 \%$ of this land mass is allotted to Administrative and Diplomatic center with an area around 4,400 hectares. A significant portion of the city was determined to incorporate a public lake and open space. Such allocation came as no surprise since the new capital followed the concept of "Intelligent Garden City," and is the first of its kind to be developed in Malaysia according to this principle [17]

Project implementation was delegated in 1996 to a unique governmental entity called the "Putrajaya Corporation" to oversee the building of the new capital. Putrajaya's urban design and planning was dictated by a "Total Planning Doctrine" to integrate the interrelationship between man and his surroundings. The doctrine laid out the association of Man and his Creator, Man-Man, and Man and Nature, which can be regarded as an advanced evolution of the Intelligent City Concept of the future [16]. This concept is correlated strongly to the concept of sustainable development and has guided physical planning of Putrajaya, and influenced the practice of planning and design in general, and gave rise to a new approach in physical planning [2]. As a direct outcome of this new approach, a vast proportion of the capital city is designated as green open space. The master plan has integrated design features to complement the natural setting of the city. An expansive man-made lake has created $38 \mathrm{~km}$ of waterfront properties within the city which is divided into 20 precincts. A core island was created to cater for commercial activities and core employment. Peripheral Housing districts are planned based on the Neighborhood Unit concept supplied with complimentary services. The master plan proposed a central Boulevard extending for $4.2 \mathrm{~km}$ that serves as the central spine, and movement axis. An unusual design feature of a city destined to be the federal capital of Malaysia is that only $5.8 \%$ of the land area will be utilized for governmental purposes. The land use plan has set aside $37 \%$ of the city's area for open space. Residential districts occupy $25.5 \%$, commercial $2.9 \%$, Roads and Utilities 18.8\%, public amenities 9.7\%, Infrastructure and Utilities $9.2 \%$, and civic and cultural land uses constitute $0.2 \%$ of the Total land area of the capital. Government land use occupied merely 5.3\% of land area [14]. 


\section{CONCLUSION}

Planning and design criteria of capital cities have evolved dramatically over the decades but rather slowly. The Garden City model is still alive despite all the many years since its initiation at the hands of Sir Ebenezer Howard in 1898. Since the mid 2oth century, the principles guiding the formulation of urban planning and design models of capital cities have developed in the right direction. Within four decades, Planning thought has taken a drastic turn away from the Automobile dominated model seen in Costa's design of Brasilia, to embracing the Intelligent Garden City concept of Putrajaya. The models keep evolving, but capital cities remain the front window of any country to showcase its identity, strength, and economic wealth. These elements are the very same factors which exert tremendous social, economic, and environmental pressures on Capital cities more than other cities within a country. The age of globalization has added new pressures on capital cities to attract tourists and investments. The future of capital cities in many countries around the world remains a pressing argument to urbanists as well as political leaders. Many countries are in the process of building new capitals, while others are contemplating relocation. In general, there are four possible scenarios to deal with this issue. Countries may build a new capital city from scratch as in the Brazilian example. Building a separate administrative center and seat of government while leaving the old capital to remain the economic and cultural hub has been adopted successfully in the Malaysian example. Malaysia chose an existing urban center to be the nucleus to erect a more livable capital or develop a new model of urban growth and development of existing capital cities. In any case, any future debate on the subject of capital cities cannot take place in isolation of the gigantic innovations in digital technology, which shattered the concept of distance and central location. In the age of electronic government, the function of capital cities is becoming more and more symbolic and ceremonial. There is a continuous need for Urban planning theorists to reconcile pressures exerted on capitals experiencing rapid urban growth, with the functional role of capitals as the showcase of nations, and an example of efficiency, progress, and livability.

\section{References}

[1] T. Hall, Planning Europe's Capital Cities, First edit. Oxford: Taylor \& Francis eLibrary, 1997.

[2] V. Rossman, Capital Cities: Varieties and Pattern of Development and Relocation. Oxen: Routledge, 2017. 
[3] D. L. A. Gordan, Ed., Planning Twentieth Century Capital Cities. Oxfordshire: Routledge, 2006.

[4] E. Schatz, "When Capital Cities Move: The Political Geography of Nation and State Building Edward Schatz Working Paper \#303-February 2003," no. February, 2003.

[5] D. M. Macedo and S. Ficher, "Brasilia: Preservation of a Modernist City (article)," Conservation Perspectives, 2013. [Online]. Available: http:// www.getty.edu/conservation/publications_resources/newsletters/28_1/ brasilia.html.

[6] B. A. Bertaud, "Brasilia spatial structure: Between the Cult of Design and Markets," no. August, pp. 1-18, 2010.

[7] G. M. S. MUbyopyo, "The influence of New Capital on the Exixting Town, Dodoma, Tanzania," University of Nairobi, 1975.

[8] A. C. Mosha, "The planning of the new capital of Tanzania: Dodoma, an unfulfilled dream," 1988.

[9] S. Koreans, "The burden of being planned. How African cities can learn from experiments - INTI - International New Town Institute." [Online]. Available: http://www.newtowninstitute.org/spip.php?article1050. [Accessed: 01-Jan2017].

[10] G. Ikoku, "The City as Public Space: Abuja - the Capital City of Nigeria," vol. 6, no. 1, pp. 34-45, 2004

[11] Nigerian Institute of Town Planners, "NITP Commends House of Reps on Abuja Master Plan Review" 2017. [Online]. Available: http://nitpng.com/nitpcommends-house-of-reps-on-abuja-master-plan-review/. [Accessed: 01-Jan2017].

[12] O. D. et al Ubani, "Physical Master-planning as Panacea to Physical Planning Challenges in Nigeria Cities: Case Study of Abuja , Nigeria Capital City," Civ. Environ. Res., vol. 6, no. 2, pp. 28-34, 2014.

[13] Mayor's Office of Astana, "MAYOR'S OFFICE OF ASTANA," 2017. [Online]. Available: http://astana.gov.kz/en/modules/material/47. [Accessed: 01-Jan-2017].

[14] H. C. Siong, "Putrajaya - Administrative Centre of Malaysia -Planning Concept and Implementation-," in Sustainable urban development and Governance conference, 2006, pp. 1-20.

[15] R. Associés, "The new city of putrajaya," 2008. [Online]. Available: http://www.richezassocies.com/en/project/398/the-new-city-of-putrajaya.

[Accessed: 01-Jan-2017]. 
[16] D. B. Omar, "The Total Planning Doctrine and Putrajaya development," in The Sustainable City III, E. T. C.A. Brebbia, Ed. WIT press, 2004, p. 10.

[17] www.ppj.gov.my, "Planning and development of putrujaya,". p. 72, 1995. 